\title{
Analisis Pengukuran Kinerja Perusahaan Dengan Konsep Kartu Skor Berimbang
}

\author{
Sri Laksmi Pardanawati ${ }^{1)}$, Rukmini ${ }^{2)}$, Muhammad Luthfi Nur Fatyasin ${ }^{3)}$ \\ ${ }^{1)}$ Program Study Akuntansi/ ITB-AAS Indonesia Surakarta \\ ${ }^{2)}$ Program Study Manajemeni/ ITB-AAS Indonesia Surakarta \\ ${ }^{3)}$ Program Study Akuntansi/ ITB-AAS Indonesia Surakarta \\ *Email korespondensi: stie.aas@gmail.com
}

\begin{abstract}
This study aims to determine the effect of partially and simultaneously financial perspective, customer perspective, internal business perspective and growth and learning perspective on the performance of PT Parama. This research uses a quantitative descriptive approach, with a sample of 33 respondents. Primary data were obtained from questionnaires filled out with questionnaires that had previously been tested for validity and reliability. Data analysis techniques used multiple linear regression analysis. The results of the research are partially known financial perspective variables partially affect the performance of PT Parama's company, customer perspective variables partially affect the company's performance of PT Parama, internal business process perspective variables partially affect PT Parama's corporate performance, variable growth and learning perspective, influential partially on the company's performance of PT Parama, while Simultaneously the financial perspective, customer perspective, internal business perspective, learning perspective and growth affect the company's performance of PT Parama
\end{abstract}

Keywords: Balanced Scorecard, financial perspective, customer perspective, internal business process perspective, learning and growth perspective, company performance

Saran sitasi: Widiastutik, A., \& Oktaviani, R. M. (2020). Analisis Pengukuran Kinerja Perusahaan Dengan Konsep Kartu Skor Berimbang. Jurnal Akuntansi dan Pajak, 21 (1), 48-58. doi:http://dx.doi.org/10.29040/jap.v21i1.795

DOI: http://dx.doi.org/10.29040/jap.v21i1.795

\section{PENDAHULUAN}

Informasi finansial dan informasi nonfinansial merupakan gambaran mengenai kinerja perusahaan. Penyusunan anggaran untuk mengendalikan biaya. merupakan Informasi finansial, sedangkan faktor kunci untuk menetapkan strategi yang dipilih guna melaksanakan tujuan yang telah ditetapkan merupakan Informasi nonfinansial. Salah satu faktor penting dalam perusahaan adalah Penilaian atau pengukuran kinerja. Karena selain digunakan untuk menilai keberhasilan perusahaan, pengukuran kinerja juga dapat digunakan sebagai dasar untuk menentukan sistem imbalan dalam perusahaan, misalnya untuk menentukan tingkat gaji karyawan maupun reward yang layak. Pihak manajemen juga dapat menggunakan pengukuran kinerja perusahaan sebagai alat untuk mengevaluasi periode yang lalu. (Hardiyanto, et al, 2005).
Kebanyakan pengukuran kinerja dan ukuran keberhasilan itu kebanyakan dinilai dari financial performance dan atau market share saja, walaupun sampai sekarang pun masih banyak yang menggunakan ukuran tersebut. Pengukuran kinerja dengan sistem ini menyebabkan orientasi perusahaan hanyalah keuntungan jangka pendek dan cenderung mengabaikan kelangsungan hidup perusahaan dalam jangka panjang. Pengukuran dengan cara ini kurang dapat menjelaskan masa lalu perusahaan dan kurang memperhatikan aspek eksternal.

Hasil penelitian yang dilakukan oleh Gimzauskiene dan Valanciene (2010) menunjukkan bahwa sistem pengukuran kinerja dalam organisasi Lithuanian akan efisien dan efektif ketika bersifat multidimensi. Korelasi kuat antara keuangan, pasar, pelanggan, proses internal, dan langkah-langkah terkait intelektual membuktikan bahwa hasil keuangan adalah titik akhir kinerja organisasi yang 
dapat dikelola sambil mengelola faktor nonkeuangan seperti pelanggan, proses, dan modal intelektual.

Panicker dan Seshadri (2013) membahas penggunaan Kartu Skor Berimbang untuk mengukur kinerja bank asing di India selama 2009 - 2012. Hasil penelitian menunjukkan bahwa kinerja pada perspektif keuangan meningkat pada 2009 - 2011. Perspektif proses internal tidak mengungkapkan perbaikan yang signifikan pada tingkat pertumbuhan tahunan rata-rata sekitar 2\%. Skor Standard Chartered Bank pada perspektif pelanggan adalah yang terburuk. Perspektif pembelajaran dan pertumbuhan menunjukkan hasil baik. Bank telah mencetak hampir $100 \%$ pada karyawan yang dinilai, pelatihan yang diterima dan keterlibatan karyawan. Hasil dari beberapa penelitian yang telah dilakukan membuktikan bahwa metode Kartu Skor Berimbang dipandang cukup komprehensif dalam mengukur kinerja perusahaan.

\section{Kinerja Perusahaan}

Kinerja perusahaan adalah suatu tampilan keadaan secara utuh atas perusahaan selama periode waktu tertentu, merupakan hasil atau prestasi yang dipengaruhi oleh kegiatan operasional perusahaan dalam memanfaatkan sumber daya-sumber daya yang dimiliki (Helfert, 1996 dalam Srimindarti, 2004:53). Kinerja merupakan suatu istilah secara umum yang digunakan untuk sebagian atau seluruh tindakan atau aktivitas dari suatu organisasi pada suatu periode dengan referensi pada jumlah standar seperti biayabiaya masa lalu atau yang diproyeksikan, dengan dasar efisiensi, pertanggungjawaban atau akuntabilitas manajemen dan semacamnya (Srimindarti, 2004: 53). Menurut pendekatan perilaku dalam manajemen, kinerja adalah kuantitas atau kualitas sesuatu yang dihasilkan atau jasa yang diberikan oleh seseorang yang melakukan pekerjaan (Luthans, 2005:165). Kinerja adalah hasil kerja baik secara kualitas maupun kuantitas yang dicapai oleh seseorang dalam melaksanakan tugas sesuai tanggung jawab yang diberikan (Mangkunagara, 2009:22). Menurut Fahmi (2013) dalam Ningsih \& Utami (2020) kinerja keuangan adalah suatu analisis yang dilakukan untuk melihat sejauh mana suatu perusahaan telah melaksanakan aturan-aturan pelaksanaan keuangan secara baik dan benar

\section{Pengertian Kartu Skor Berimbanag ( Balanced Scorecard)}

Menurut Munawir (2002: 437) pengertian Kartu Skor Berimbang adalah: "Suatu kartu skor yang digunakan untuk merencanakan skor yang hendak diwujudkan oleh seseorang di masa depan dan untuk mencatat skor hasil kinerja yang sesungguhnya dicapai oleh seseorang". Menurut Yuwono (2003: 8) mengemukakan bahwa Kartu Skor Berimbang merupakan suatu system manajemen; pengukuran dan pengendalian yang secara cepat; tepat dan komprehensif dapat memberikan pemahaman kepada manajer tentang kinerja bisnis. Menurut Mulyadi (2007) mengemukakan bahwa Kartu Skor Berimbang merupakan alat manjemen kontemporer yang didesain untuk meningkatkan kemampuan perusahaan dalam melipatgandakan kinerja keuangan luar biasa secara berkesinambungan (rustainable outstanding financial performance).

\section{Perspektif Kartu Skor Berimbang}

Kalpan dan Norton (2000: 22) mengemukakan bahwa Kartu Skor Berimbang terdiri dari empat perspektif yakni : perspektif keuangan, perspektif pelanggan, perspektif proses bisnis internal, dan perspektif pembelajaran dan pertumbuhan

\section{a. Perspektif Keuangan}

Pengukuran keuangan mempunyai dua peranan penting. Pertama adalah semua perspektif tergantung pada pemgukuran keuangan yang menunjukkan implementasi dari strategi yang sudah direncanakan. Kedua adalah memberi dorongan kepada 3 perspektif yang lainnya tentang target yang harus dicapai dalam mencapai tujuan organisasi. Menurut Kaplan dan Norton (2000)

\section{b. Perspektif Pelanggan}

Pelanggan memiliki peranan penting dalam kehidupan perusahaan. Sebuah perusahaan yang tumbuh dalam persaingan tidak akan mungkin dapat bertahan apabila tidak didukung oleh pelanggan. Loyalitas tolak ukur pelanggan dilakukan dengan terlebih dahulu melakukan pemetaan terhadap segmen pasar yang akan menjadi target atau sasaran. Apa yang menjadi keinginan dan kebutuhan para pelanggan menjadi hal yang penting dalam perspektif ini.

\section{c. Perspektif Proses Bisnis Internal}

Analisis proses bisnis internal perusahaan dilakukan dengan menggunakan analisis rantai 


\section{Jurnal Akuntansi dan Pajak, 21 (01), 2020, 50}

nilai. Manajemen mengidentifikasi proses bisnis internal kritis yang harus diunggulkan oleh perusahaan. Kartu Skor Berimbang dalam perspektif ini memungkinkan manajer untuk mengetahui seberapa baik bisnis mereka berjalan dan apakah produk dan atau jasa mereka sesuai dengan spesifikasi pelanggan (Sony Yuwono, et al, 2004:36).

\section{d. Perspektif Pembelajaran dan Pertumbuhan}

Perspektif terakhir dalam Kartu Skor Berimbang mengembangkan tujuan dan ukuran yang mendorong pembelajaran dan pertumbuhan perusahaan. Tujuan di dalam perspektif pembelajaran dan pertumbuhan adalah menyediakan infrastruktur yang memungkinkan tujuan ambisius dalam tiga perspektif lainnya tercapai. Tujuan dalam perspektif pembelajaran dan pertumbuhan merupakan faktor pendorong dihasilkannya kinerja yang istimewa dalam tiga perspektif Kartu Skor Berimbang yang pertama.

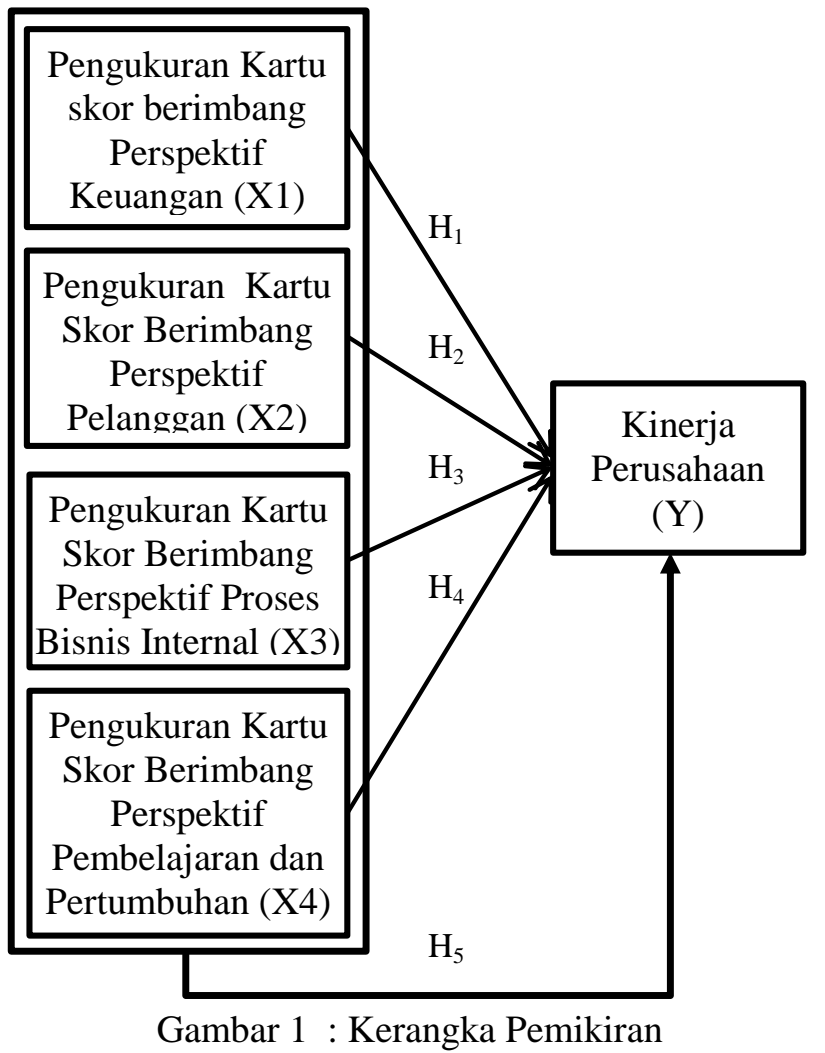

\section{Hipotesis}

H1: perspektif keuangan berpengaruh secara parsial terhadap kinerja perusahaan PT Parama.

$\mathrm{H} 2$ : perspektif pelanggan berpengaruh secara parsial terhadap kinerja perusahaan PT Parama.

H3: perspektif bisnis internal berpengaruh secara parsial terhadap kinerja perusahaan PT Parama.
H4: perspektif pertumbuhan dan pembelajaran berpengaruh secara parsial terhadap kinerja perusahaan PT Parama.

H5: perspektif keuangan, perspektif pelanggan, perspektif bisnis internal, perspektif pembelajaran dan pertumbuhan berpengaruh secara simultan terhadap kinerja perusahaan PT Parama.

\section{METODO PENELITIAN}

\section{Populasi dan Sampel}

Populasi adalah suatu kumpulan menyeluruh dari suatu obyek yang merupakan perhatian peneliti (Ronny Kountur, 2004: 9). Populasi dalam penelitian ini adalah karyawan dan pelanggan PT. Parama Cabang Surakarta. Untuk karyawan PT. Parama berjumlah 50 orang, maka kami akan menggunakan rumus Slovin untuk menentukan jumlah karyawan, sebagai berikut :

dimana :

$$
\mathrm{n}=\frac{\mathrm{N}}{1+N e^{2}}
$$

$$
\begin{array}{ll}
\mathrm{n} & \text { : jumlah sampel } \\
\mathrm{N} & \text { : jumlah populasi } \\
\mathrm{e} & \text { : batas toleransi kesalahan }(10 \%)
\end{array}
$$

maka

$$
\begin{aligned}
& \mathrm{n}=\frac{50}{1+\left\{50 \cdot(0,10)^{2}\right\}} \\
& \mathrm{n}=33,333
\end{aligned}
$$

dan diperoleh hasil 33,333.

Jadi jumlah karyawan yang akan digunakan sebanyak 33 orang.

Sampel adalah bagian dari jumlah dan karakteristik yang dimili oleh populasi tersebut (Sugiyono; 2010). Sampel dalam penelitian ini adalah responden yang mengisi kuesioner dengan menjawab pertanyaan-pertanyaan yang ada, yaitu karyawan dan pelanggan. Untuk kuesioner pelanggan, sampel diambil menggunakan simple random sampling yaitu teknik pengambilan sampel yang dilakukan secara acak sebanyak 33 pelanggan

\section{Data Penelitian}

\section{a. Jenis Data dan Sumber Data}

Data yang akan digunakan dalam penelitian ini adalah data primer. Data primer adalah data yang dikumpulkan langsung dari obyeknya (J. Supranto, 1993: 8). Data primer dapat berupa opini subyek secara individual atau kelompok, hasil observasi 


\section{Jurnal Akuntansi dan Pajak, 21 (01), 2020, 51}

terhadap suatu benda, kejadian atau kegiatan dan hasil-hasil pengujian. Peneliti dengan menggunakan data primer dapat mengumpulkan data sesuai dengan yang diinginkan. Data primer yang digunakan dalam penelitian ini adalah penyebaran kuesioner kepada responden baik karyawan PT. PARAMA dan pelanggan atau konsumen.

\section{b. Teknik Pengumpulan Data}

Untuk kegiatan ini kami mengunjungi langsung pada perusahaan tempat penelitian dengan maksud untuk mengumpulkan data secara observasi, dan pembagian kuesioner.

1) Observasi; merupakan teknik pengmpulan data dengan cara melakukan pengamatan secara langsung terhadap obyek yang diteliti.

2) Pembagian Kuesioner; diperlukan untuk mengukur kepuasan pelanggan dan kepuasan karyawan.

\section{Variabel Penelitian}

Variable penelitian adalah obyek penelitian atau apa yang menjadi titik perhatian suatu penelitian (Arikunto 1998, h.118). Variabel dalam penelitian ini terdiri dari variable bebas $(\mathrm{X})$ dan variable terikat (Y).

a. Variable Bebas (independent) adalah variable yang mempengaruhi variable terikat (Arikunto, 1998 : 118). Variable bebas dalam penelitian ini terdiri dari:

1) Perspektif Keuangan (X1)

2) Perspektif Pelanggan (X2)

3) Perspektif Proses Bisnis Internal (X3)

4) Perspektif Pertum buhan dan Pembelajaran (X4)

b. Variable Terikat (dependent) adalah variable yang dipengaruhi variable bebas (Arikunto 2006: 118). variable terikat dalam penelitian ini adalah kinerja perusahaan $(\mathrm{Y})$.

\section{Uji Instrumen Peneliti}

Data yang dihasilkan dari pengukuran kepuasan pelanggan dan kepuasan karyawan (dengan kuesioner) akan dianalisis dengan "Skala Likert" dengan pembobotan sebagai berikut :
5 : sangat puas
$4:$ puas
3 : cukup puas
$2:$ tidak puas
1 : sangat tidak puas

\section{a. Uji Validitas}

Uji validitas ini dilakukan dengan tujuan untuk melihat sejauh mana ketepatan dari alat pengukur untuk mengukur apa yang ingin diukur. Uji validitas ini mengggunakan metode person correlation dengan memanfaatkan alat bantu berupa Statistical Package For The Social Science (SPSS). Menurut pedoman aturan umum bahwa butir yang diuji dinyatakan valid apabila angka $\mathrm{r}$ hitung > r tabel.

\section{b. Uji Reliabilitas}

Uji reliabilitas dalam penelitian ini dilakukan dengan menghitung cronbach's alpha dari masing-masing instrument dengan menggunakan alat bantu berupa Statistical Package For The Social Science (SPSS). Alasan penilaian menggunakan teknik cronbach's alpha adalah untuk mencari reliabilitas instrument yang skornya merupakan rentangan dari beberapa nilai yang berbeda-beda. Butir yang diuji dan dinyatakan reliabel jika cronbach alpha $\geq 0,6$ (Arikunto, 1998).

\section{Pengujian Hipotesis}

\section{a. Analisis Regresi Linier Berganda}

Analisis regresi linier berganda adalah hubungan secara linier antara dua atau lebih variable independent $\left(\mathrm{X}_{1}, \mathrm{X}_{2, \ldots} \ldots \mathrm{X}_{\mathrm{n}}\right)$ dengan variable dependen (Y). Analisis ini untuk mengetahui arah hubungan antara variable independen dengan variable dependen apakah masing-masing variable independen berhubungan positif atau negative dan untukk memprediksi nilai variable dependen apabila nilai variable independen mengalami kenaikan atau penurunan. Data yang digunakan biasanya berskala interval atau rasio. Persamaan regresi linier berganda sebagai berikut :

$Y^{\prime}=a+b_{1} X_{1}+b_{2} X_{2}+\ldots . .+b_{n} X_{n}$

Keterangan:

Y' : variable dependen (nilai yang diprediksikan)

$\mathrm{X}_{1} \& \mathrm{X}_{2}$ : variable independen

a : konstanta (nilai $\mathrm{Y}^{\prime}$ apabila $\left.\mathrm{X}_{1}, \mathrm{X}_{2}, \ldots . . \mathrm{X}_{\mathrm{n}}=0\right)$

$\mathrm{b} \quad$ : koefisien regresi (nilai peningkatan/penurunan) 


\section{Jurnal Akuntansi dan Pajak, 21 (01), 2020, 52}

\section{b. Uji t}

Uji t digunakan untuk menguji secara parsial masing-masing variabel. Jika probabilitas nilai $t$ atau signifikansi $<0,05$ maka dapat dikatakan bahwa terdapat pengaruh antara variabel bebas terhadap variabel terikat secara parsial. Namun, jika probabilitas atau signifikansi > 0,05 maka dapat dikatakan bahwa tidak terdapat pengaruh yang signifikan antara masing-masing variabel bebas terhadap variabel terikat. Uji t juga bisa dilakukan dengan bantuan software SPSS.

\section{c. Uji F}

Uji $\mathrm{F}$ digunakan untuk mengetahui pengaruh variable bebas secara bersama-sama (simultan) terhadap variable terikat. Signifikan berarti hubungan yang terjadi dapat berlaku untuk populasi. Penggunaan tingkat signifikansinya beragam, tergantung keinginan peneliti, misalkan $0,05(5 \%)$. Jika nilai probabilitas $<0,05$ maka dapat dikatakan terdapat pengaruh yang signufikan secara bersama-sama antara variabel bebas terhadap variabel terikat. Namun, jika nilai signifikansi > 0,05 maka tidak terdapat pengaruh yang signifikan secara bersama-sama antara variabel bebas terhadap variabel terikat. Uji F bisa dilakukan dengan bantuan software SPSS.

\section{d. Uji Koefisien Determinasi $\left(\mathbf{R}^{2}\right)$}

Uji ini bertujuan untuk menentukan pressentase total variasi dalam variabel terikat yang diterangkan oleh variabel bebas. Hasil perhitungan Adjusted $R^{2}$ dapat diketahui berapa persentase yang dapat dijelaskan oleh variabelvariabel bebas terhadap variabel terikat. Sedangakan sisanya dipengaruhi atau dijelaskan oleh variabel-variabel lain yang tidak dimasukkan dalam model penelitian. Langkah mencari koefisien determinasi bisa dilakukan dengan bantuan SPSS. Nilai koefisien determinasi adalah antara 0 dan 1 . Nilai $R^{2}$ yang kecil berarti kemampuan variabel independen sangat terbatas. $\mathrm{R}^{2}$ dikatakan baik apabila mendekati 1 . Jika $\mathrm{R}^{2}$ sama dengan 1 berarti bahwa variabel independen berpengaruh sempurna terhadap variabel dependen. Sedangkan bila $\mathrm{R}^{2}$ sama dengan 0 , maka tidak ada pengaruh variabel independen terhadap variabel dependen.

\section{HASIL DAN PEMBAHASAN}

a. Hasil

Pengujian instrumen dalam penelitian ini meliputi pengujian validitas dan reliabilitas, berikut akan dijelaskan satu per atu secara rinci.

\section{1) Uji Validitas}

Uji validitas ini dilakukan dengan tujuan untuk melihat sejauh mana ketepatan dari alat pengukur untuk mengukur apa yang ingin diukur. Uji validitas ini mengggunakan metode person correlation dibantu dengan program SPSS versi 20.0. Menurut pedoman aturan umum bahwa butir yang diuji dinyatakan valid apabila taraf signifikansi yang dihasilkan $\leq 0,05$. Dan instrumen valid apabila angka $r$ hitung $>r$ tabel.

\section{a) Variabel Perspektif Keuangan $\left(X_{1}\right)$}

Hasil pengujian variabel perspektif keuangan $\left(\mathrm{X}_{1}\right)$ dapat dijelaskan sebagaimana terlihat pada tabel 1 sebagai berikut.

Tabel 1

Hasil Uji Validitas Perspektif Keuangan $\left(\mathrm{X}_{1}\right)$

\begin{tabular}{|c|c|c|c|}
\hline $\begin{array}{c}\text { Butir } \\
\text { Pernyataan }\end{array}$ & $\mathrm{r}_{\mathrm{xy}}$ & $\mathrm{r}_{\text {tabel }}$ & Keterangan \\
\hline 1 & 0,671 & 0,344 & Valid \\
\hline 2 & 0,814 & 0,344 & Valid \\
\hline 3 & 0,814 & 0,344 & Valid \\
\hline 4 & 0,863 & 0,344 & Valid \\
\hline 5 & 0,812 & 0,344 & Valid \\
\hline
\end{tabular}

Sumber: hasil olahan data SPSS, 2020

Nilai $r_{\text {tabel }}$ untuk sampel sebesar 33 dengan taraf signifikansi 0,05 adalah 0,344 . Tabel 1 menunjukkan bahwa semua butir pernyataan variabel perspektif keuangan $\left(\mathrm{X}_{1}\right)$ adalah valid. Hal ini dikarenakan semua butir pernyataan mempunyai nilai $\mathrm{r}_{\text {hitung }}(0,671$ $-0,836)$ lebih besar dari nilai $r_{\text {tabel }}(0,344)$. Dengan demikian kelima butir pernyataan variabel perspektif keuangan $\left(\mathrm{X}_{1}\right)$ dinyatakan valid.

\section{b) Variabel Perspektif Pelanggan $\left(\mathbf{X}_{2}\right)$}

Hasil pengujian variabel perspektif pelanggan $\left(\mathrm{X}_{2}\right)$ dapat dijelaskan sebagaimana terlihat pada tabel 2 sebagai berikut:

Tabel 2

Hasil Uji Validitas Perspektif Pelanggan $\left(\mathrm{X}_{2}\right)$

\begin{tabular}{|c|c|c|c|}
\hline $\begin{array}{c}\text { Butir } \\
\text { Pernyataan }\end{array}$ & $\mathrm{r}_{\mathrm{xy}}$ & $\mathrm{r}_{\text {tabel }}$ & Keterangan \\
\hline 1 & 0,720 & 0,344 & Valid \\
\hline 2 & 0,638 & 0,344 & Valid \\
\hline 3 & 0,730 & 0,344 & Valid \\
\hline
\end{tabular}


Jurnal Akuntansi dan Pajak, 21 (01), 2020, 53

\begin{tabular}{|c|c|c|c|}
\hline $\begin{array}{c}\text { Butir } \\
\text { Pernyataan }\end{array}$ & $\mathrm{r}_{\mathrm{xy}}$ & $\mathrm{r}_{\text {tabel }}$ & Keterangan \\
\hline 4 & 0,791 & 0,344 & Valid \\
\hline 5 & 0,829 & 0,344 & Valid \\
\hline 6 & 0,743 & 0,344 & Valid \\
\hline 7 & 0,725 & 0,344 & Valid \\
\hline 8 & 0,791 & 0,344 & Valid \\
\hline 9 & 0,819 & 0,344 & Valid \\
\hline 10 & 0,801 & 0,344 & Valid \\
\hline 11 & 0,787 & 0,344 & Valid \\
\hline 12 & 0,703 & 0,344 & Valid \\
\hline 13 & 0,686 & 0,344 & Valid \\
\hline
\end{tabular}

Sumber: hasil olahan data SPSS, 2020

\section{c) Variabel Perspektif Proses Bisnis Internal $\left(\mathbf{X}_{3}\right)$}

Hasil pengujian variabel perspektif proses bisnis internal $\left(\mathrm{X}_{3}\right)$ dapat dijelaskan sebagaimana terlihat pada tabel 3 sebagai berikut:

Tabel 3

Hasil Uji Validitas

Perspektif Proses Bisnis Internal $\left(\mathrm{X}_{3}\right)$

\begin{tabular}{|c|c|c|c|}
\hline $\begin{array}{c}\text { Butir } \\
\text { Pernyataan }\end{array}$ & $\mathrm{r}_{\mathrm{xy}}$ & $\mathrm{r}_{\text {tabel }}$ & Keterangan \\
\hline 1 & 0,715 & 0,344 & Valid \\
\hline 2 & 0,784 & 0,344 & Valid \\
\hline 3 & 0,746 & 0,344 & Valid \\
\hline 4 & 0,770 & 0,344 & Valid \\
\hline 5 & 0,695 & 0,344 & Valid \\
\hline 6 & 0,740 & 0,344 & Valid \\
\hline 7 & 0,758 & 0,344 & Valid \\
\hline 8 & 0,790 & 0,344 & Valid \\
\hline
\end{tabular}

Sumber: hasil olahan data SPSS, 2020

Nilai $r_{\text {tabel }}$ untuk sampel sebesar 33 dengan taraf signifikansi 0,05 adalah 0,344. Tabel.3 menunjukkan bahwa semua butir pernyataan variabel perspektif proses bisnis internal $\left(\mathrm{X}_{3}\right)$ adalah valid. Hal ini dikarenakan semua butir pernyataan mempunyai nilai $r_{\text {hitung }}(0,695-0,790)$ lebih besar dari nilai $r$ tabel $(0,344)$. Dengan demikian kedelapan butir pernyataan variabel perspektif proses bisnis internal $\left(\mathrm{X}_{3}\right)$ dinyatakan valid.

\section{d) Variabel Perspektif Pertumbuhan dan \\ Pembelajaran $\left(\mathbf{X}_{4}\right)$}

Hasil pengujian variabel perspektif pertumbuhan dan pembelajaran $\left(\mathrm{X}_{4}\right)$ dapat dijelaskan sebagaimana terlihat pada tabel 4 sebagai berikut:

Tabel 4

Hasil Uji Validitas

Perspektif Pertumbuhan dan Pembelajaran $\left(\mathrm{X}_{4}\right)$

\begin{tabular}{|c|c|c|c||}
\hline $\begin{array}{c}\text { Butir } \\
\text { Pernyataan }\end{array}$ & $\mathrm{r}_{\mathrm{xy}}$ & $\mathrm{r}_{\text {tabel }}$ & Keterangan \\
\hline 1 & 0,712 & 0,344 & Valid \\
\hline 2 & 0,731 & 0,344 & Valid \\
\hline 3 & 0,895 & 0,344 & Valid \\
\hline 4 & 0,826 & 0,344 & Valid \\
\hline 5 & 0,818 & 0,344 & Valid \\
\hline 6 & 0,843 & 0,344 & Valid \\
\hline
\end{tabular}

Sumber: hasil olahan data SPSS, 2020

Nilai $r_{\text {tabel }}$ untuk sampel sebesar 33 dengan taraf signifikansi 0,05 adalah 0,344 . Tabel 4 menunjukkan bahwa semua butir pernyataan variabel perspektif pertumbuhan dan pembelajaran $\left(\mathrm{X}_{4}\right)$ adalah valid. Hal ini dikarenakan semua butir pernyataan mempunyai nilai $r_{\text {hitung }}(0,712-0,895)$ lebih besar dari nilai $r_{\text {tabel }}$ $(0,344)$. Dengan demikian keenam butir pernyataan variabel perspektif pertumbuhan dan pembelajaran $\left(\mathrm{X}_{4}\right)$ dinyatakan valid.

\section{e) Variabel Kinerja Perusahaan (Y)}

Hasil pengujian variabel kinerja perusahaan (Y) dapat dijelaskan sebagaimana terlihat pada tabel .5 sebagai berikut.

Tabel .5

Hasil Uji Validitas Kinerja Perusahaan (Y)

\begin{tabular}{|c|c|c|c|}
\hline $\begin{array}{c}\text { Butir } \\
\text { Pernyataan }\end{array}$ & $\mathrm{r}_{\mathrm{xy}}$ & $\mathrm{r}_{\text {tabel }}$ & Keterangan \\
\hline 1 & 0,734 & 0,344 & Valid \\
\hline 2 & 0,711 & 0,344 & Valid \\
\hline 3 & 0,750 & 0,344 & Valid \\
\hline 4 & 0,837 & 0,344 & Valid \\
\hline 5 & 0,645 & 0,344 & Valid \\
\hline 6 & 0,627 & 0,344 & Valid \\
\hline 7 & 0,801 & 0,344 & Valid \\
\hline
\end{tabular}

Sumber: hasil olahan data SPSS, 2018

Nilai $r_{\text {tabel }}$ untuk sampel sebesar 33 dengan taraf signifikansi 0,05 adalah 0,344 . Tabel .5 menunjukkan bahwa semua butir pernyataan variabel kinerja perusahaan (Y) adalah valid. Hal ini dikarenakan semua butir pernyataan mempunyai nilai $\mathrm{r}_{\text {hitung }}(0,645$ - 0,837) lebih besar dari nilai $r_{\text {tabel }}(0,344)$. Dengan demikian ketujuh butir pernyataan variabel kinerja perusahaan (Y) dinyatakan valid. 


\section{Jurnal Akuntansi dan Pajak, 21 (01), 2020, 54}

\section{2) Uji Reliabilitas}

Uji reliabilitas dalam penelitian ini dilakukan dengan menghitung cronbach's alpha dari masingmasing instrument dengan menggunakan program SPSS versi 20.0. Butir yang diuji dan dinyatakan reliabel jika cronbach alpha $\geq 0,6$. Hasil uji reliabilitas untuk masing-masing variabel dapat dijelaskan sebagaimana terlihat pada tabel 6 .

Tabel 6

\section{Hasil Uji Reliabilitas Instrumen Penelitian}

\begin{tabular}{|l|c|c|c|}
\hline Variabel & $\begin{array}{c}\text { Conbach } \\
\text { Alpha }\end{array}$ & $\begin{array}{c}\text { Nilai } \\
\text { Kritis }\end{array}$ & Ket \\
\hline Perspektif Keuangan $\left(\mathrm{X}_{1}\right)$ & 0,854 & 0,6 & Reliabel \\
\hline $\begin{array}{l}\text { Perspektif Pelanggan } \\
\left(\mathrm{X}_{2}\right)\end{array}$ & 0,936 & 0,6 & Reliabel \\
\hline $\begin{array}{l}\text { Perspektif Proses Bisnis } \\
\text { Internal }\left(\mathrm{X}_{3}\right)\end{array}$ & 0,886 & 0,6 & Reliabel \\
\hline $\begin{array}{l}\text { Perspektif Pertumbuhan } \\
\text { dan Pembelajaran }\left(\mathrm{X}_{4}\right)\end{array}$ & 0,891 & 0,6 & Reliabel \\
\hline Kinerja Perusahaan $(\mathrm{Y})$ & 0,849 & 0,6 & Reliabel \\
\hline
\end{tabular}

Sumber: hasil olahan data SPSS, 2020

Hasil uji reliabilitas instrumen diperoleh nilai cronbach alpha masing-masing variabel $\geq 0,6$. Hasil pengujian reliabilitas setiap variabel penelitian secara lengkap . Dengan demikian seluruh instrumen variabel penelitian dinyatakan reliabilitas dapat diterima atau reliabel.

\section{3) Hasil Pengujian Hipotesis}

\section{a) Analisis Regresi Linier Berganda}

Analisis regresi linier berganda ini digunakan untuk mengetahui pengaruh variabel independen terhadap variabel dependen. Adapun hasil dari analisis regresi linier berganda dapat dijelaskan sebagaimana terlihat pada tabel 7 .

\section{Tabel 7}

Hasil Analisis Regresi Linier Berganda

\begin{tabular}{|l|c|c|}
\hline \multicolumn{1}{|c|}{ Variabel Independen } & B & $\begin{array}{c}\text { Standard } \\
\text { eror }\end{array}$ \\
\hline Konstanta & 1,147 & 2,587 \\
\hline Perspektif Keuangan $\left(\mathrm{X}_{1}\right)$ & 0,347 & 0,130 \\
\hline Perspektif Pelanggan $\left(\mathrm{X}_{2}\right)$ & 0,134 & 0,039 \\
\hline $\begin{array}{l}\text { Perspektif Proses Bisnis Internal } \\
\left(\mathrm{X}_{3}\right)\end{array}$ & 0,247 & 0,101 \\
\hline $\begin{array}{l}\text { Perspektif Pertumbuhan dan } \\
\text { Pembelajaran }\left(\mathrm{X}_{4}\right)\end{array}$ & 0,273 & 0,116 \\
\hline
\end{tabular}

Sumber: hasil olahan data SPSS, 2020
Dari tabel 7 dapat disusun persamaan regresi sebagai berikut:

$\mathrm{Y}=1,147+0,347 \mathrm{X}_{1}+0,134 \mathrm{X}_{2}+0,247 \mathrm{X}_{3}+0,273 \mathrm{X}_{4}$ $+\mathrm{e}$

Dari persamaan regresi tersebut, adapun interpretasi yang dapat dijelaskan adalah sebagai berikut:

(1) Nilai konstanta sebesar 1,147 ini dapat diartikan apabila nilai variabel perspektif keuangan, perspektif pelanggan, perspektif proses bisnis internal serta perspektif pertumbuhan dan pembelajaran bernilai 0 maka kinerja perusahaan sebesar 1,147.

(2) Nilai koefisien regresi untuk variabel perspektif keuangan sebesar 0,347 artinya apabila perspektif keuangan meningkat 1 point, maka kinerja perusahaan meningkat sebesar 0,347 point.

(3) Nilai koefisien regresi untuk variabel perspektif pelanggan sebesar 0,134 artinya apabila perspektif pelanggan meningkat 1 point, maka kinerja perusahaan meningkat sebesar 0,134 point.

(4) Nilai koefisien regresi untuk variabel perspektif proses bisnis internal sebesar 0,247 artinya apabila perspektif proses bisnis internal meningkat 1 point maka kinerja perusahaan meningkat sebesar 0,247 point.

(5) Nilai koefisien regresi untuk variabel perspektif pertumbuhan dan pembelajaran sebesar 0,273 artinya apabila perspektif pertumbuhan dan pembelajaran meningkat 1 point maka kinerja perusahaan meningkat sebesar 0,273 point.

b) Uji t

Tabel 8

Hasil Uji t

\begin{tabular}{|l|c|c|c|c||}
\hline \multicolumn{1}{|c|}{ Variabel } & $\mathbf{t}_{\text {hitung }}$ & $\mathbf{t}_{\text {tabel }}$ & $\boldsymbol{p}_{\text {value }}$ & Simpulan \\
\hline $\begin{array}{l}\text { Perspektif } \\
\text { Keuangan }\left(\mathrm{X}_{1}\right)\end{array}$ & 2,677 & 2,048 & 0,012 & Signifikan \\
\hline $\begin{array}{l}\text { Perspektif } \\
\text { Pelanggan }\left(\mathrm{X}_{2}\right)\end{array}$ & 3,401 & 2,048 & 0,002 & Signifikan \\
\hline $\begin{array}{l}\text { Perspektif Proses } \\
\text { Bisnis Internal }\left(\mathrm{X}_{3}\right)\end{array}$ & 2,461 & 2,048 & 0,020 & Signifikan \\
\hline $\begin{array}{l}\text { Perspektif } \\
\text { Pertumbuhan dan } \\
\text { Pembelajaran }\left(\mathrm{X}_{4}\right)\end{array}$ & 2,362 & 2,048 & 0,025 & Signifikan \\
\hline
\end{tabular}

Sumber: hasil olahan data SPSS, 2020 


\section{Jurnal Akuntansi dan Pajak, 21 (01), 2020, 55}

Berdasarkan tabel 8 dapat diketahui bahwa variabel perspektif keuangan memiliki nilai $t$ hitung sebesar 2,677 lebih besar dari $t_{\text {tabel }}$ sebesar 2,048 dengan nilai signifikansi $0,012<0,05$ yang artinya perspektif keuangan berpengaruh secara parsial terhadap kinerja perusahaan PT Parama. Oleh karena itu, hipotesis pertama $\left(\mathrm{H}_{1}\right)$ diterima.

Sedangkan untuk variabel perspektif pelanggan memiliki nilai $\mathrm{t}$ hitung sebesar 3,401 lebih besar dari $t_{\text {tabel }}$ sebesar 2,048 dengan nilai signifikansi $0,002<0,05$ yang artinya perspektif pelanggan berpengaruh secara parsial terhadap kinerja perusahaan PT Parama. Oleh karena itu, hipotesis kedua $\left(\mathrm{H}_{2}\right)$ diterima.

Variabel perspektif proses bisnis internal memiliki nilai $\mathrm{t}$ hitung sebesar 2,461 lebih besar dari $\mathrm{t}_{\text {tabel }}$ sebesar 2,048 dengan nilai signifikansi $0,020<0,05$ yang artinya perspektif proses bisnis internal berpengaruh secara parsial terhadap kinerja perusahaan PT Parama. Oleh karena itu, hipotesis ketiga $\left(\mathrm{H}_{3}\right)$ diterima.

Variabel perspektif pertumbuhan dan pembelajaran memiliki nilai $t_{\text {hitung }}$ sebesar 2,362 lebih besar dari $t_{\text {tabel }}$ sebesar 2,048 dengan nilai signifikansi $0,025<0,05$ yang artinya perspektif pertumbuhan dan pembelajaran berpengaruh secara parsial terhadap kinerja perusahaan PT Parama. Oleh karena itu, hipotesis keempat $\left(\mathrm{H}_{4}\right)$ diterima.

\section{c) $\mathbf{U j i} \mathbf{F}$}

Uji $F$ digunakan untuk mengetahui pengaruh variable bebas secara bersama-sama (simultan) terhadap variable terikat. Jika nilai probabilitas $<0,05$ maka dapat dikatakan terdapat pengaruh yang siufikan secara bersama-sama antara variabel bebas terhadap variabel terikat. Namun, jika nilai signifikansi > 0,05 maka tidak terdapat pengaruh yang signifikan secara bersama-sama antara variabel bebas terhadap variabel terikat. Hasil uji $\mathrm{F}$ dapat dijelaskan sebagaimana terlihat pada tabel 4.9 sebagai berikut.

\section{Tabel 9}

Hasil Uji F

\begin{tabular}{|l|c|c|c|c|}
\hline $\begin{array}{l}\text { Model } \\
\text { penelitian }\end{array}$ & $\mathrm{F}_{\text {hitung }}$ & $\mathrm{F}_{\text {tabel }}$ & $p_{\text {value }}$ & Simpulan \\
\hline $\begin{array}{l}\text { Kinerja } \\
\text { Perusahaan } \\
(\mathrm{Y})\end{array}$ & 33,957 & 2,71 & 0,000 & Signifikan \\
\hline
\end{tabular}

Sumber: hasil olahan data SPSS, 2020
Pada tabel 9 dapat dilihat bahwa nilai $F_{\text {hitung }}$ sebesar 33,957> $\mathrm{F}_{\text {tabel }}(2,71)$ dengan probabilitas sebesar 0,000 ( $\left.p_{\text {value }}<0,05\right)$. Hal ini berarti perspektif keuangan, perspektif pelanggan, perspektif bisnis internal, perspektif pembelajaran dan pertumbuhan berpengaruh secara simultan terhadap kinerja perusahaan PT Parama, sehingga hipotesis kelima $\left(\mathrm{H}_{5}\right)$ diterima. Hal ini juga menunjukkan bahwa model regresi yang digunakan adalah fit atau sehat (goodness of fit).

\section{d) Uji Koefisien Determinasi $\left(\mathbf{R}^{2}\right)$}

Uji ini bertujuan untuk menentukan prosentase total variasi dalam variabel terikat yang diterangkan oleh variabel bebas. Hasil perhitungan Adjusted $R^{2}$ dapat diketahui berapa persentase yang dapat dijelaskan oleh variabel-variabel bebas terhadap variabel terikat.

Tabel 10

Hasil Uji Koefisien Determinasi

\begin{tabular}{|l|c|r|c|c|}
\hline Model & $\mathrm{R}$ & $\begin{array}{c}\mathrm{R} \\
\text { Square }\end{array}$ & $\begin{array}{c}\text { Adjusted } \\
\text { R Square }\end{array}$ & $\begin{array}{c}\text { Std. Error of the } \\
\text { Estimate }\end{array}$ \\
\hline 1 & $0.911^{\mathrm{a}}$ & 0.829 & 0.805 & 1.31213 \\
\hline
\end{tabular}

a. Predictors: (Constant), perspektif pertumbuhan dan pembelajaran, perspektif pelanggan, perspektif keuangan, perspektif proses bisnis internal Sumber: hasil olahan data SPSS, 2018

Berdasarkan hasil analisis diperoleh nilai Adjusted- $R^{2}$ sebesar 0,805 sehingga dapat diinterpretasikan bahwa keempat variabel sebagai tolok ukur Kartu Skor Berimbang yang meliputi perspektif keuangan, perspektif pelanggan, perspektif bisnis internal, perspektif pembelajaran dan pertumbuhan mampu menjelaskan terhadap variasi perubahan variabel kinerja perusahaan sebesar $80,5 \%$ sedangkan sisanya sebesar $19,5 \%$ dijelaskan oleh variabel lain yang tidak digunakan dalam penelitian ini.

\section{b. Pembahasan Hasil Penelitian}

Dalam Kartu Skor Berimbang tujuan dan ukuran dikembangkan kedalam empat perspektif yaitu: perspektif keuangan, perspektif konsumen, perspektif proses bisnis, dan perspektif pembelajaran dan pertumbuhan dalam rangka pengukuran kinerja perusahaan. Kartu Skor Berimbang tidak hanya sebagai alat pengukur kinerja perusahaan yang komprehensif, tetapi merupakan suatu bentuk 
transformasi strategik secara total kepada seluruh tingkatan dalam organisasi.

\section{1) Pengaruh Perspektif Keuangan Terhadap Kinerja Perusahaan}

Berdasarkan analisis data diketahui perspektif keuangan berpengaruh positif dan signifikan terhadap kinerja perusahaan. Dimana terbukti dari uji t terlihat bahwa t hitung $(2,677)$ lebih besar $t$ tabel $(2,048)$ dengan signifikansi $0,012<0,05$ sehingga hipotesis pertama diterima. Perspektif keuangan berpengaruh positif terhadap kinerja perusahaan disini dapat diartikan bahwa PT Parama sudah memfokuskan sasaran kinerja perspektif keuangan pada salah satu tahap dalam siklus bisnis seperti yang dikemukakan oleh Kaplan dan Norton. Selain itu PT. Parama sudah menerapkan evaluasi kinerja baik dari perspektif keuangan maupun non keuangan, dan terlihat nampak adanya keseimbangan terhadap nilai perusahaan sesungguhnya. PT Parama selain mengandalkan pengukuran kinerja bersifat finansial yang bersumber dari laporan keuangan, dan juga secara terintegrasi dilakukan pengukuran kinerja lain yang bersifat non finansial, sehingga data tersebut mampu menunjukkan efisiensi dan kemampuan perusahaan secara keseluruhan. Hal ini akan berdampak positif terhadap kinerja perusahaan secara efektif dalam meningkatkan perspektif keuangan.

Hasil penelitian ini mendukung hasil penelitian sebelumnya yang dilakukan oleh Lokatili dan Devie (2013); Aryane dan Norita (2015); dan Faishol (2016) dimana perspektif keuangan sebagai tolok ukur pengukuran Kartu Skor Berimbang memberikan pengaruh positif terhadap kinerja perusahaan.

\section{2) Pengaruh Perspektif Pelanggan Terhadap Kinerja Perusahaan}

Berdasarkan analisis data diketahui perspektif pelanggan berpengaruh positif dan signifikan terhadap kinerja perusahaan. Dimana terbukti dari uji $\mathrm{t}$ terlihat bahwa $\mathrm{t}$ hitung $(3,401)$ lebih besar $\mathrm{t}$ tabel $(2,048)$ dengan signifikansi $0,002<0,05$ sehingga hipotesis kedua diterima. Jadi hal ini menunjukkan bahwa manajemen PT Parama sudah menerapkan sasaran-sasaran strategik yang benar-benar ditujukan untuk memuaskan kebutuhan pelanggan. Hal ini ditunjukkan bahwa mayoritas pelanggan merasa puas akan pelayanan yang diberikan karyawan PT Parama sesuai harapan pelanggan, sehingga kedepannya PT Parama harus lebih memperhatikan pelanggan atau customer agar tetap puas dengan pelayanan yang diberikan kepada pelanggan bahkan mampu meningkatkan kepuasan mereka agar lebih loyal terhadap PT Parama dan tidak pindah ke perusahaan lainnya.

Hasil penelitian ini mendukung hasil penelitian Tandiontong, dkk (2011); Kurniawanto (2013); dan Yunitasari (2016) yang menyatakan bahwa perspektif pelanggan yang diukur dengan customer satisfaction mempunyai pengaruh positif dan signifikan terhadap kinerja perusahaan.

\section{3) Pengaruh Perspektif Proses Bisnis Internal Terhadap Kinerja Perusahaan}

Karyawan PT Parama menyatakan puas terhadap penilaian perspektif proses bisnis internal sebagai tolok ukur Balanced Scorecard. Hal ini dapat diartikan bahwa penilaian tentang gaya kepemimpinan, beban kerja, inovasi pelayanan, prosedur penanganan perusahaan terhadap pengembalian produk rusak, sarana dan prasarana dalam perusahaan untuk memberikan pelayanan, pelayanan perusahaan terhadap pelanggan dalam hal pengiriman barang tepat waktu, kelengkapan peralatan untuk melakukan pekerjaan dan inovasi produk mayoritas karyawan memberikan persepsi puas karena secara keseluruhan pernyataan sesuai dengan harapan karyawan.

Berdasarkan analisis data diketahui perspektif proses bisnis internal berpengaruh positif dan signifikan terhadap kinerja perusahaan. Dimana terbukti dari uji t terlihat bahwa t hitung $(2,461)$ lebih besar $t$ tabel $(2,048)$ dengan signifikansi $0,020<0,05$ sehingga hipotesis ketiga diterima. Pengaruh perspektif proses bisnis internal terhadap kinerja manajemen diatas selaras dengan penelitian yang telah dilakukan oleh Kasnawati (2011); Yunitasari (2016); dan Faishol (2016) yang menyatakan bahwa perspektif proses bisnis internal mempunyai pengaruh positif dan signifikan terhadap kinerja manajemen. Jadi semakin baik proses bisnis internal maka pelanggan akan merasa puas sehingga kinerja dari perusahaan itu akan mengalami peningkatan.

\section{4) Pengaruh Perspektif Pertumbuhan dan Pembelajaran Terhadap Kinerja Perusahaan}

Dari hasil analisis statistik deskriptif variabel yang merupakan penilaian responden tentang sasaran kinerja dalam perspektif pertumbuhan dan pembelajaran, dapat disimpulkan bahwa hasilnya mayoritas karyawan PT Parama memberikan persepsi puas terkait perspektif pertumbuhan dan pembelajaran yang selama ini mereka rasakan sesuai 


\section{Jurnal Akuntansi dan Pajak, 21 (01), 2020, 57}

harapan mereka selama menjadi karyawan PT. Parama sebagai tolok ukur Balanced Scorecard.

Berdasarkan analisis data diketahui perspektif pembelajaran dan pertumbuhan berpengaruh positif dan signifikan terhadap kinerja perusahaan. Dimana terbukti dari uji t terlihat bahwa thitung $(2,362)$ lebih besar $t$ tabel $(2,048)$ dengan signifikansi $0,025<0,05$ sehingga hipotesis keempat diterima. Jadi semakin tinggi tingkat kepuasan karyawan yang diimplementasikan oleh PT Parama akan berdampak langsung terhadap kinerja perusahaan PT Parama itu sendiri. Perspektif akhir dari Kartu Skor Berimbang ini akan memelihara daya tahan hidup perusahaan. Oleh karenanya, kinerja manajemenpun akan meningkat dengan dilakukannya perbaikan dalam hal pembelajaran dan pertumbuhan perusahaan.

Hasil penelitian ini juga sejalan dengan hasil penelitian yang dilakukan oleh Kasnawati (2011); Aryane dan Norita (2015); dan Faishol (2016) yang menyatakan bahwa perspektif pembelajaran dan pertumbuhan mempunyai pengaruh positif dan signifikan terhadap kinerja perusahaan.

5) Pengaruh Perspektif Keuangan, Perspektif Pelanggan, Perspektif Bisnis Internal, Perspektif Pembelajaran dan Pertumbuhan terhadap Kinerja Perusahaan.

Berdasarkan hasil analisis data uji $\mathrm{F}$ diketahui keempat variabel Kartu Skor Berimbang yang dapat dipandang sesuai dengan pertimbangan bahwa konsep ini, mampu menyeimbangkan kinerja financial dan non financial berpengaruh positif dan signifikan terhadap kinerja perusahaan secara simultan. Dimana terbukti dari uji F terlihat bahwa F hitung $(33,957)$ lebih besar $F$ tabel $(2,71)$ dengan signifikansi $0,000<0,05$ sehingga hipotesis kelima diterima ini. Dengan adanya pengukuran strategis, tujuan serta program tindakan dari masing-masing perspektif dapat memberikan pengaruh terhadap peningkatan kinerja perusahaan PT Parama. Jadi dapat disimpulkan bahwa baik secara teori maupun praktik Kartu Skor Berimbang berpengaruh terhadap kinerja manjemen. Hal ini dikarenakan Kartu Skor Berimbang sebagai sebuah sistem manajemen (bukan hanya pada sitem pengukuran) yang memungkinkan perusahaan untuk menjelaskan strategi, menerjemahkannya ke dalam sebuah aksi, dan menyediakan umpan balik yang berarti. BSC memberikan umpan balik baik dari sisi bisnis internal dan hasil eksternal dengan tujuan memperbaiki kinerja stratejik dan hasil.
Hasil penelitian ini mendukung hasil penelitian yang diakukan Kasnawi (2011); Yunitasari (2016); dan Faishol (2016); dimana ada pengaruh penerapan Kartu Skor Berimbang yang meliputi empat perspektif yaitu perspektif keuangan, pespektif pelanggan, perspektif proses bisnis internal dan persepktif pembelajaran dan pertumbuhan secara simultan terhadap kinerja perusahaan.

\section{KESIMPULAN}

Penelitian ini bertujuan untuk mengetahui pengaruh penerapan Kartu Skor Berimbang yang terdiri dari empat perspektif yaitu perspektif keuangan, pespektif pelanggan, perspektif proses bisnis internal dan persepktif pembelajaran dan pertumbuhan terhadap kinerja perusahaan PT Parama. Berdasarkan uraian pada hasil dan pembahasan maka dapat diambil kesimpulan sebagai berikut:

a. Perspektif keuangan berpengaruh secara parsial terhadap kinerja perusahaan PT Parama terbukti dari nilai $\mathrm{t}$ hitung $(2,677)>\mathrm{t}$ tabel $(2,048)$ dengan signifikansi $0,012<0,05$ sehingga $\mathrm{H}_{1}$ diterima. Artinya semakin tinggi perspektif keuangan maka akan meningkatkan kinerja perusahaan. Hal ini berarti PT Parama efektif dalam meningkatkan perspektif keuangan dan sesuai harapan karyawan sehingga karyawan merasa puas.

b. Perspektif pelanggan berpengaruh secara parsial terhadap kinerja perusahaan PT Parama terbukti dari nilai $\mathrm{t}$ hitung $(3,401)>\mathrm{t}$ tabel $(2,048)$ dengan signifikansi $0,002<0,05$ sehingga $\mathrm{H}_{2}$ diterima. Artinya semakin tinggi perspektif pelanggan maka akan meningkatkan kinerja perusahaan. PT Parama senantiasa berupaya meningkatkan kepuasan pelanggan, salah satunya dengan adanya kotak saran di perusahaan dan sebagai wadah pernyataan puas atau tidak puasnya pelanggan.

c. Perspektif proses bisnis internal berpengaruh secara parsial terhadap kinerja perusahaan PT Parama terbukti dari nilai $\mathrm{t}$ hitung $(2,461)>\mathrm{t}$ tabel $(2,048)$ dengan signifikansi $0,020<0,05$ sehingga $\mathrm{H}_{3}$ diterima. Artinya semakin tinggi perspektif proses bisnis internal maka akan meningkatkan kinerja perusahaan. Hal ini dikarenakan PT Parama senantiasa melakukan pengukuran kinerja terhadap para karyawan dari keempat perspektif tersebut, serta selalu ada 


\section{Jurnal Akuntansi dan Pajak, 21 (01), 2020, 58}

ujian kenaikan jabatan baik setelah peluncuran produk baru maupun setiap semester.

d. Perspektif pertumbuhan dan pembelajaran berpengaruh secara parsial terhadap kinerja perusahaan PT Parama terbukti dari nilai t hitung $(2,362)>\mathrm{t}$ tabel $(2,048)$ dengan signifikansi $0,025<0,05$ sehingga $\mathrm{H}_{4}$ diterima. Artinya semakin tinggi perspektif pembelajaran dan pertumbuhan maka akan meningkatkan kinerja perusahaan. Hal ini bisa saja terjadi karena PT Parama senantiasa meluncurkan produk baru dan melakukan perbaikan dan pengevaluasian baik untuk memuaskan para karyawannya maupun pelangganya

e. Perspektif keuangan, perspektif pelanggan, perspektif bisnis internal, perspektif pembelajaran dan pertumbuhan berpengaruh secara simultan terhadap kinerja perusahaan PT Parama, terbukti dari nilai F hitung $(33,957)>\mathrm{F}$ tabel $(2,71)$ dengan signifikansi $0,000<0,05$ sehingga $\mathrm{H}_{5}$ diterima. Hal ini membuktikan, apabila perspektif keuangan, perspektif pelanggan, perspektif proses bisnis internal, serta perspektif pembelajaran dan pertumbuhan secara terus menerus dan bersama-sama akan memberikn pengaruh yang sangat positif terhadap kinerja perusahaan.

\section{SARAN}

Berdasarkan kesimpulan diatas, maka penulis memberikan beberapa rekomendasi sebagai berikut:

a. Bagi PT Parama

Diharapkan PT Parama dapat lebih meningkatkan evaluasi kinerja perusahaan pada keempat perspektif Balanced Scorecard, agar lebih dapat mengimplementasikan pengukuran kinerja perusahaan dengan metode Kartu Skor Berimbang secara utuh yaitu dengan perspektif keuangan maupun non keuangan.

b. Penulis selanjutnya

1) Diharapkan dapat menetapkan standarstandar yang jelas dalam pengukuran kinerja perusahaan yang dijadikan objek penelitian

2) Perlu dilakukan pengkajian lebih dalam terhadap hasil-hasil yang telah dicapai serta upaya mengevaluasi kembali program tindakan yang telah dilakukan setelah periode implementasi dilaksanakan pada periode tertentu agar tujuan dari masing-masing perspektif dapat tercapai secara optimal.

3) Diharapkan peneliti dapat memperluas obyek penelitian agar hasil dapat digeneralisasikan secara umum dan memvariasikan variabel lainnya yang dapat mempengaruhi kinerja perusahaan.

\section{UCAPAN TERIMAKASIH}

Diucapkan terimakasih kepada Pengurus Jurnal Akuntansi dan Pajak ( JAP ) ITB - AAS INDONESIA Surakarta yang telah menerbitkan jurnal dengan judul Analisis Pengukuran Kinerja Perusahaan Dengan Konsep Kartu Skor Berimbang.

\section{REFERENSI}

Arikunto, Suharsimi. 2010. Prosedur Penelitian: Suatu Pendekatan Praktik. Jakarta: PT. Rineka Cipta.

Kurniawanto, Hudi. 2013. "Pengaruh Keempat Perspektif Balanced Scorecard Terhadap Kinerja Seka Swalayan Sragen”. Jurnal Universitas Kristen Satya Wacana Sragen Vol 5 no 2 Mei 2013 Hal 61 - 84

Mulyadi.2009. Sistem Terpadu Pengelolaan Kinerja

Personel Berbasis Balanced Scorecard.

Yogyakarta: Unit Penerbit dan Percetakan Sekolah Tinggi Ilmu Manajemen YKPN

Ningsih, S., \& Utami, W. B. (2020). Pengaruh Operating Leverage dan Struktur Modal terhadap Kinerja Keuangan pada Perusahaan Go Publik Sektor Property Dan Real Estate. Jurnal Akuntansi dan Pajak, 20(2), 154-160.

Srimindarti, Ceacilia. (2004). Balanced Scrorecard Sebagai Alternatif Pengukuran Kinerja. Jurnal Akuntansi, 7(1), 52- 64.

Sugiyono. 2017. Metode Penelitian Kualitatif (Untuk penelitian yang bersifat : eksploratif, enterpretif, interaktif dan konstruktif). Bandung : Alfabeta.

Widodo, Iman. 2011. Analisis Perusahaan dengan Menggunakan Pendekatan Balanced Scorecard studi kasus pada Perusahaan Mebel PT Jansen Indonesia. Semarang : Universitas Diponorogo Semarang.

Yuwono, Sonny. 2004. Petunjuk Praktis Penyusunan Balanced Scorecard. Jakarta: PT. Gramedia Pustaka Utama. 